\title{
]3[
}

\section{The Phoenissae}

In the central scene of Euripides' Phoenissae (834-IOI8), the prophet Tiresias enters to inform Creon that the city of Thebes will not survive the attack of Polyneices and his allies unless Creon's younger son, Menoeceus, the last of the pureborn sown men of Thebes, is sacrificed to appease Ares; ${ }^{1}$ Creon's elder son, Haimon, is unavailable because he is betrothed to Antigone. For many generations Ares has nursed his wrath over the slaughter of the dragon, and he now demands a sacrifice or sphagia (sphagenta, 933) as restitution for the crime that founded the city. Creon, instantly abandoning the patriotism that he previously professed, resists Tiresias' proposal by plotting to send his son through the battle lines into exile. But Menoeceus, af ter seeming to acquiesce in this plan, deceives his father and departs alone to sacrifice himself at the dragon's den.

The sacrificial death of Menoeceus has been interpreted by some critics as the central action and positive climax of a play in which all the characters except Menoeceus, Jocasta, and Antigone display inappropriate or untraditional attitudes to family and city. ${ }^{2}$ Others

A shorter version of this chapter was first delivered in the spring of 1980 at a Princeton University conference in honor of J.-P. Vernant.

${ }^{1}$ On voluntary sacrificial action in Euripides, see Schmitt I92 I, Roussel I922, Strohm I957: 50-63, Burnett I97I: 22-26, Vellacott 1975: I78-204, and, exclusively on the Phoenissae, Rebuffat 1972.

'For generally positive interpretations of Menoeceus' sacrifice, see especially Voigt I 896, Reimschneider I940, Pohlenz I954, Strohm 1957, Garzya 1962, de 
have found yet another example of Euripidean irony in the isolation of this act of selfless heroism from the rest of an "episodic and overstuffed drama" (as the author of one ancient argument to the play called it). ${ }^{3}$

Both groups of critics are partially correct, for the play seems to offer two discrete and mutually exclusive readings of Menoeceus' action, which means one thing in the light of the choral odes and Tiresias' speech about the need for the sacrifice, and another from the perspective of the rest of the stage action. The choral odes, as Grube pointed out, seem designed to frame closely Menoeceus' action: no other Greek tragedy crowds three stasima into four hundred lines at the center of the play, with one brief ode as a tag. ${ }^{4}$ These odes, as many critics have seen, form a continuous song cycle. 5 They offer a consistent and connected reading of the history and prehistory of Thebes. The chorus celebrates Menoeceus' action as continuing the series of confrontations between Theban kings and mythic monsters that has already pitted Cadmus against the dragon and Oedipus against the Sphinx. Menoeceus' patriotic sacrifice atones for the original crime of violence that founded the city and has continued to haunt it ever since. This original action, presided over by the goddess Athena, also had sacrificial overtones, as the use of the word chernibas (sacrificial waters, 662) at the killing of the dragon implies. 6 Tiresias' report that the gods require Menoeceus' sacrifice probably surprised the Athenian audience, for

Romilly 1967, Rawson 1970, Arthur 1975, and Burian in Burian and Swann I98 I. Arthur, Rawson, Reimschneider, and Schmitt I92I especially emphasize the themes of family and fatherland first discussed by Hartung i 843: 442-44.

${ }^{3}$ For recent interpretations of Menoeceus' death as ironic, see esp. Vellacott i 975 and Conacher I967a: 24I-42. Vellacott (203) argues that Euripides uses scenes of voluntary sacrifice to show that war justifies every crime and creates a quasireligious authority that masks barbaric emotions. Mastronarde 1974 makes a more cautious pessimistic interpretation; as he remarks (2I 5 n. 2I), could Euripides have invented Menoeceus' sacrifice only to debunk it?

${ }^{4}$ Grube I94 I: 37 I.

${ }^{5}$ On the odes, see esp. Kranz I933: 228ff.; Reimschneider I 940 passim, esp. I $5 \mathrm{ff}$. and 28ff.; Arthur I977; and Parry I978: I66-73. Burian in Burian and Swann I98I follows Arthur in linking his interpretation of Menoeceus to the odes.

6 Vian I963, esp. 232-34, shows that the founding acts of Cadmus follow a predictable mythical pattern, which includes a sacrifice to propitiate the local deity. 


\section{Ritual Irony}

the episode is generally agreed to be a Euripidean innovation. 7 But it is not surprising in the light of the choral odes, which locate it in a historical context shaped by divine forces.

The death of Menoeceus, as Ludwig has shown, also marks the center of a symmetrically ordered plot. ${ }^{8}$ Jocasta's prologue is answered in the closing scene by the laments of Oedipus, Antigone, and Creon; these framing scenes emphasize the troubled history of the house of Laius. Antigone's lyrics in the next scene, the teichoskopia (the viewing from the wall), match her lyric laments, initially alone and then with Oedipus, near the end of the play. Jocasta's failure to reconcile the brothers Eteocles and Polyneices in a long debate receives a reply in the messenger's description of their fatal duel. The central episode, the death of Menoeceus, is framed by Creon's and Eteocles' plan for the coming battle and the messenger's report of that battle. Yet despite these axial symmetries and the central place given in the action to Menoeceus' death, the chorus alone gives his gesture the recognition and praise that it deserves (I054-66). 9 In contrast, the messenger who describes the battle between the Argives and the Spartans gives Menoeceus a mere three lines in a subordinate clause (1090-92):

When the child of Creon had died for his country, standing on the tower tops and piercing his throat with a black-bound sword to save the land, ...

Creon's later intent to mourn his son properly is forestalled by the absence of Jocasta, who has left the palace in an attempt to prevent the duel between her two sons, and again by the arrival of the messenger announcing the deaths of Jocasta, Polyneices, and Eteocles. Menoeceus' body may well have lain untended and un-

7For the question of Euripides' invention of the Menoeceus episode, see esp. Schmitt I92 I: 88-93. Vian I963: 206-Is has inconclusively contested this view. To argue that Meneoceus performs a comparable function in the myth to Melanippus, Megareus, and Haimon might argue for the creativity and aptness of Euripides' invention rather than for the actual existence of a Menoeceus in the tradition. See also Zielinski i 924. 202.

${ }^{8}$ Ludwig I954, esp. I30-35.

${ }^{9}$ Macaria's sacrificial death in the Heracleidae also receives no further notice, but her act is publicly celebrated before her death. 
mourned onstage for some part of the ensuing scene, a visual reminder of a heroic death ignored throughout the remaining dramatic action. ${ }^{10}$ Although Menoeceus has won an onoma gennaion (noble reputation), Creon, as he mourns his son, stresses not his glory, but the pain he has brought to his father (I3I4).

More important, throughout the remaining action it is unclear in precisely what sense Menoeceus' self-sacrifice has succeeded in ensuring the safety of the city. The initial battle letween the Thebans and the Argives ends in a draw, owing to the intervention of Zeus' thunderbolt on the side of Thebes (I I 80-88). This clearly divine influence on the battle apparently represents the mark of Menoeceus' sacrifice on the action. But the war is by no means over at this point. Though Thebes is saved, the Argives have not been defeated, and Polyneices and Eteocles eventually offer to decide their conflict by individual combat. They kill each other, but Thebes then defeats the Argive army because, unlike the enemy, the Thebans keep their shields during the duel. This act of prométhia (forethought, I 466) hardly suggests a further imprint of divinity on the battle.

Yet even this battle apparently does not complete the saving of the city, despite Tiresias' emphasis on the death of Menoeceus. Tiresias says before the battle that the best strategy for rescuing Thebes, for which the sacrifice of Menoeceus was a substitute or alternative (allè mèchanè sōtèrias, another means of salvation, 890), would have been the explusion of ton Oidipou (the offspring of Oedipus, not "those around Oedipus," 886), who are possessed by a daimōn and about to destroy Thebes. In the Phoenissae, Oedipus has survived his sons, and af ter the battle Creon plans to carry out Tiresias' previously unheeded advice by exiling the ancient king from the land. Nevertheless, Creon's belated act of patriotism is suspect from several angles. ${ }^{11}$ First, the Creon who was unwilling

${ }^{10}$ Mastronarde I 974: 2 I 3 n. 4 and 502-3 argues, contrary to the usual interpretation of I3I7, that Creon does not enter with Menoeceus' body. He asserts that Creon has left it at home and has come to search for Jocasta to perform the proper mourning ritual. The text seems far less clear than Mastronarde implies.

${ }^{11}$ For bibliography on Creon's order to banish Oedipus and its relation to Tiresias' oracle, see Mastronarde I 974: 225-28. Creon's detractors outnumber his defenders. The literary tradition, though it insists on the death of the brothers, does not require the banishment of Oedipus. If Euripides meant Creon's act to be a 


\section{Ritual Irony}

to carry out Tiresias' suggestion and sacrifice his son to save Thebes, and who is willing to abandon Eteocles' instructions to complete the marriage of Antigone and Haimon, executes here a plan proposed neither by Eteocles nor by Tiresias, who gave no instructions concerning Oedipus himself. In Tiresias' speech the sacrifice of Menoeceus was an alternative pharmakon (cure) to ensure the safety of the city (893). Oedipus' curse has been fulfilled, and the offspring of Oedipus have been removed from the city by their mutual death. At the point in the play where Creon decides to exile Oedipus, the Argives have already been defeated and Thebes, at least for the moment, "saved." Oedipus himself has already won from the audience some sympathy for his plight. It cannot help but feel that Creon may be distorting and stretching the words of the prophet in order to consolidate his own advantage and power, and that the piety of Menoeceus has in fact set no abiding example for the rulers of Thebes.

Finally, Menoeceus departs with these words (IOI5-I8):

If each man would take his available goods and devote them to the common good of his country, cities would experience fewer evils and would be fortunate in the future.

Thebans, however, share such selfless patriotism only to the degree that they do not have power. Jocasta anticipates these sentiments in her debate with Polyneices and Eteocles, who scarcely listen and themselves make way for the Creon whom we see making apparently self-serving fiats at the end of the play. If Menoeceus' idealism has achieved precisely nothing in reconciling public and private interests, how can his ritual death have contributed to the city's actual salvation?

The difficulty in establishing a satisfactory reading of the death of Menoeceus, then, seems deliberately compounded by Euripides. Menoeceus, having died gloriously according to the account of the chorus, but with uncertain effect in the action, leaves the audience in doubt as to what meaning to confer on his ritual sacrifice.

late but correct response to Tiresias' earlier warnings about the house of Laius, he certainly has left open the possibility of doubt and ambiguity. 


\section{The Phoenissae}

Conacher locates this puzzle in the play's "series of paradoxical confrontations of the world of myth (in which the pattern of events is determined by some external and supernatural force) and the 'real' world of Euripidean drama, whose events are usually presented as the result of human passions and human folly." 12 Conacher's suggestion, although it needs to be made more precise, offers a useful starting point for an analysis. In the Phoenissae Euripides, as we have suggested, creates a contrapuntal relation between the action and the choral odes. That is, the chorus of foreign women sings a history of Thebes in mythical terms, a history in which the acts of divinities leave a clear and unquestioned trace. In the action of the play Tiresias' prophecy, Menoeceus' death, the thunderbolt, and the influence of tuche still reflect divine interest, but it is human plans and passions that actually propel events. Nevertheless, as in all Greek tragedy, no events in either realm are determined entirely by the gods (nor, I think, by men), and the course of the action and the display of character are not strictly naturalistic.

An examination of Menoeceus' death, then, must proceed from two directions. As in the case of the $I A$, we shall consider the sacrifice first from the perspective of the stage action and then from the perspective of the odes. Finally, insofar as a corrupt text allows, we shall explore how the counterpoint established between the world of myth created in the odes and the naturalistic world of the action shapes our interpretation of the sacrifice. 13

${ }^{12}$ Conacher I967a: 233, criticized by Mastronarde I974: I I2, who objects that this attempt to separate myth and reality is impossible in Greek drama; myth is what the poet makes it, and reality is the stage world created in the play. For further discussion of divine and human causation in the play, see esp. Treves I930, who finds that the play consistently denies divine care for men and justice; as well as Arthur 1975: 39-42; Mastronarde 1974, esp. 284-86; and Burian in Burian and Swann I98I: 5-6, all of whom stress that the end specified by myth is largely reached in the action of this play, if not in the Theban past, by human means.

${ }^{13}$ It is difficult to offer a coherent literary interpretation of a text that has aroused so much controversy. Extensive discussion of textual issues is beyond the scope of this book. Nevertheless, a convincing reading of the play can indirectly contribute to a defense of the received text. Mastronarde 1974 has eloquently defended the greater part of the text against the extensive attack of Fraenkel i963. A similar defense by Erbse i 966 has recently been attacked by Reeve 1972. Haslam i 975 (contested by van der Valk I 982 ) and I 976 has brought papyrological evidence to bear on the question. The exodus and problems on individual passages are discussed in later notes. For a history of the textual controversy on the Phoenissae, see esp. Mastronarde 1974 and Arthur 1975. 


\section{Ritual Irony}

The action in fact reveals a consistent strategy governing an apparently inconsistent and overcrowded plot. Those in political power at Thebes nearly succeed in allowing private interests to overcome the public welfare. They constantly and deliberately threaten to undermine the myth with their self-serving expediency. Creon, for example, tries to prevent Menoeceus' sacrifice. Eteocles is unwilling to meet with Tiresias and almost refuses to adopt the traditional battle plan; the brothers forestall their father's curse by delaying their fatal duel. Menoeceus' sacrifice, coming at the center of this wildly veering plot, redirects the action to its myth and gives it a remarkable symmetry. The brothers complete their duel, the enemy is defeated, and the family of Oedipus is permanently removed from Thebes. Finally, whereas Jocasta's initial attempt to save the city by reconciling the brothers fails, Antigone, though probably unable to bury her brother, takes advantage of Oedipus' exile to make the second successful selfless gesture of the play, this time for family rather than city, as she accompanies her father to Athens. Women and children act in this play for the higher interests of the city, the family, and the gods, all of which are abandoned by those in power but kept in the audience's awareness by the choral lyrics. The words and actions of Menoeceus, Jocasta, Antigone, and the chorus, like those of Iphigenia in the $I A$, symbolically close the gap between action and odes, again despite an overall impression that these isolated idealistic actions have in no sense cured the politics of Thebes.

\section{The Action}

A late Euripidean play can be as important for the play that it is not as for the one that it is, an effect frequently called parody. His Electra, for example, disproves to Orestes' old tutor the credibility of the footprints and the lock of hair that sufficed to identify Orestes in Aeschylus' Libation Bearers (Electra 524-44). In the Orestes, as Burnett and Zeitlin have shown, Euripides makes multiple and of ten contradictory allusions to earlier poetic texts and especially to Aeschylus' Oresteia, thus creating an uneasy juxtaposition of the novel and the familiar that more often under- 
mines than reinforces the surface meaning of the action. ${ }^{14}$ Sophocles responded to Aeschylus' interpretation of the Orestes myth, as Aeschylus did to that of Homer and the lyric poets. But Euripides heightens the effect well beyond what one normally finds in a traditional literature. The Orestes does not derive its unity from a coherent muthos, consistent characters, or even themes that work together. Indeed, the action has no fully independent meaning but develops in large part through its critical response to earlier texts.

The Phoenissae is equally insistent in invoking and abusing tradition, though not to the same effect as the Orestes. Although much of the epic, lyric, and tragedy dealing with Thebes and the house of Laius is lost, there are clear allusions in the Phoenissae to the Iliad, to Aeschylus' Seven against Thebes, to Sophocles' Oedipus Rex (if the text at this point. is genuine), and to Euripides' own Erechtheus. The grammarian Aristophanes observes in his hypothesis to the Phoenissae: "This plot, with the exception of Jocasta, is set down in Aeschylus' Seven against Thebes." The plot of the Phoenissae, then, apparently resembles that of Aeschylus' Seven more than that of any other tragedy known to Aristophanes. Revivals of Aeschylus were occurring at this period, and Aeschylus' works had already achieved a unique and privileged status as classics, to which the parodies in the Electra and Orestes are clearly responding. The Phoenissae, while reacting both specifically and in terms of typical scenes to the entire earlier tradition, seems to invoke most extensively the literary tradition represented in Aeschylus' Seven. 15 Reading the Phoenissae against this literary tradition can help to illuminate the role of Menoeceus in what appears to be a disordered and inconsistent plot and to make it clear why the radical surgery performed on the text by generations of philologists is not in principle necessary.

In the Seven the chorus states that the oracle of Apollo warned Laius that if he had no offspring the city would be saved $(742-49)$.

\footnotetext{
${ }^{14}$ Burnett I97I and Zeitlin I980. My own discussion of the action of the Ploenissae was enriched by an oral report given by John Heath in a seminar of mine at Stanford.

${ }^{15}$ Most critics of the play give passing attention to a comparison of the two plays and have briefly acknowledged Euripides' most obvious references to the Seven: Phoen. 748-52 and the emphasis on the family Erinys at 624 and 700 .
} 


\section{Ritual Irony}

In this final play of Aeschylus' trilogy, the city is indeed finally saved when Eteocles and Polyneices end the line of Laius by their mutual slaughter and when the arrogant, impious Argives find their match in the Spartoi, the autochthonous sown men who devote themselves with praiseworthy modesty to the mother earth who bore them. A conflict between state and family and between male and female stands at the center of the drama. Two confrontations between Eteocles and the women of the city, who form the chorus, frame a shield scene in which Eteocles symbolically defeats the enemy and entraps himself in the family curse as he announces the deployment of warriors at the seven gates of the city; a final disputed scene involves the mourning of the brothers and a conflict over the burial of Polyneices.

In Euripides' Phoenissae, as in Aeschylus' play, Thebes is apparently "saved" by the extinction and expulsion of the race of Laius from Thebes (see Tiresias' oracle) and by the heroic death of a sown man, Menoeceus. A conflict between city and family, male and female, similarly pervades the plot. At points Euripides seems to encourage expectations for a reprise of an Aeschylean version of a scene, only to dash them. The Pedagogue, for example, leads us to expect a chorus of women as troublesome and disorderly as they were in Aeschylus, whereas Euripides' chorus is in fact orderly and distant. Elsewhere the poet at first refuses to provide an Aeschylean shield scene but later grants it in an unexpected form, and he makes Antigone obliged to give Polyneices a burial that she is apparently unable to carry out. From this perspective the action of Euripides' play must be interpreted as much in the light of its omissions, additions, and failed promises as in the light of the actual development of the action onstage, which is far from necessary and probable at any point. 16 Accordingly, we shall begin by

${ }^{16}$ Wilamowitz I 903, esp. 588, Kitto 1954, Ebener 1964, and Conacher 1967a doubt the unity of the drama and emphasize the lack of necessity and probability in the action. Others have identified various sources of unity in the play. Podlecki I962 finds unity in the repetition of themes and images concerning light and darkness, beasts, victory, and the joyless dance; Grube I94 I and Valgiglio I 96 I find it in the emphasis on the fate of Oedipus and his sons. Reimschneider I 940 argues (esp. I9) that the hero of the play is Thebes and that the drama unfolds as a series of conflicts between the destroyers of the state and its defenders; Menoeceus' sacrifice is thus the climax of the drama, which finds closure in the death of the destructive sons of Oedipus and in the expulsion of Oedipus, the innocent bearer 
examining the action as a scene-by-scene response by Euripides to the known literary tradition and especially to the tradition as it is represented in Aeschylus' Seven. This analysis will show that the play acquires its meaning in large part by calling attention first to its of ten outrageous differences from, and finally to its similarities to, these earlier poetic texts.

Eteocles and Jocasta open the Seven and the Phoenissae respectively by offering a plan to save the city. (Compare the similar energetic patriotism of Theban rulers such as Oedipus at the opening of the $O T$ and even Pentheus in the later Bacchae.) As a general maintaining control and planning effectively for the safety of the city, Eteocles aligns himself with the pure patriots, the sown men of Thebes. Only later does he emerge fully as the Cadmean son of Oedipus, the victim of the family curse. Whereas the Aeschylean Eteocles views the hysterical prayers of the chorus of women as inimical to the city's interests, 17 in the Phoenissae a woman, Jocasta, who has, contrary to the known tradition, survived up to the moment of the battle between her sons, 18 steps in to rectify the irresponsible behavior of the male members of her family. Whereas

of miasma. Strohm 1957 finds structural coherence in a series of Responsionen: the two agones between the brothers, the exile of Polyneices and Oedipus, the two appearances of Antigone, and the doubling of the role of the brothers and Menoeceus. Rawson I970: I25 finds the play a demonstration that selfishness and selflessness toward family and fatherland appear in different forms, but that fatherland is always to be set above all other values. De Romilly i967, esp. I i 6, has a similar view. Arthur 1975 argues that the play, and especially the sacrifice of Menoeceus, shows that self-interest and justice cannot coincide; hence the final scene shifts the dilemma outside the limits of the polis and individualism. Mastronarde I 974: $286 \mathrm{ff}$. states that the play shows a series of failures to act effectively and thus reflects an essential pessimism about the conditions of human existence. Yet he believes the play is in some sense unified by its repetition of themes (such as betrayal and reconciliation, exile, family, and city) and by showing the full complexity of the downfall of Thebes in human, divine, historical, public, and private terms. Burian in Burian and Swann I98I (published after this chapter's presentation as a paper) shares my emphasis on the self-destructive and willful pursuit of selfish ends by Creon and the brothers.

${ }^{17} \mathrm{On}$ the confrontation between Eteocles and the chorus of women and the importance of the gods to which the women pray, see Benardete I 967.

${ }^{18}$ In the Lille Stesichorus fragment (P. Lille 76a, b, c), the unnamed mother of Eteocles and Polyneices seems temporarily to settle the quarrel between her sons, though almost certainly at the time of the original division of the inheritance. The dialogue here may have inspired Euripides' characterization of Jocasta in the Phoenissae, particularly in the mother's emphasis on the survival of the fatherland. 


\section{Ritual Irony}

Eteocles in the Seven tries to minimize in his speech the role of the family Erinys, Jocasta, as of ten in Euripides, brings the skeletons out of the closet at once. Family has played the determining role in the disasters of Thebes. She emphasizes from the first the fatal meaning hidden in the names of her husband and children $(26,56-$ 58), rather than allowing this meaning to emerge, as in the Seven, in a terrifying and magical fashion. ${ }^{19}$ Laius conceived Oedipus in a drunken fit $(2 \mathrm{I}-22)$ and intentionally insulted Oedipus at the crossroads (37-42); Eteocles and Polyneices mistreated their father, who cursed them in a state of sickness (63-68); Eteocles broke his word to Polyneices $(7 \mathrm{I}-76)$. The rulers of Euripides' Thebes have deliberately and consistently subordinated the interests of both family and state to their own desires, and here they abandon the safety of the city to a woman.

Jocasta's prologue, in typically Euripidean fashion, establishes an innovative direction for the myth and lays the basis for a more explicit parody of tradition in the second scene, which clearly urges the audience to view Euripides' Antigone in relation to the Iliad's Helen and Aeschylus' chorus of women in the Seven.

Neither the entrance of the chorus nor the promised debate between Eteocles and Polyneices immediately follows Jocasta's prologue. Instead there is a scene from the private world sufficiently surprising and apparently irrelevant that a few scholars have excised it without convincing textual grounds; 20 this is the teichoskopia, in which Antigone and the Pedagogue observe the Argives deployed for battle from some raised vantage point above the stage, just as Helen and Priam in Iliad 3 observe the Hellenic army from the walls of Troy. In Aeschylus' Seven, Eteocles' initial monologue is followed by the appearance of a scout who has just been among the enemy and who reports to Eteocles that they have been casting lots to decide at which gate each of the seven will be

\footnotetext{
${ }^{19}$ Mastronarde I 974: 29-3 I sees in the references to naming in the prologue a possible parody of Aeschylus.

${ }^{20}$ There are other examples in Euripides of scenes that intervene between the prologue and the chorus, but this one surprised critics as early as the author of the second argument, who finds the scene poorly integrated into the action of the play. Af ter Morus and Hermann, the major critics of the teichoskopia (although not all propose its excision from the text) are Schroeder I906, Verrall I 895: 233-39, and Dihle i $98 \mathrm{I}$.
} 
stationed. The nearly hysterical chorus of women then enters, terrified by the sounds of war into abandoning their homes to pray on the protected acropolis. In the teichoskopia of the Phoenissae the Pedagogue has performed nearly the same functions as Aeschylus' scout. He has just been among the enemy to make a truce with Polyneices (95-98). But here he reports, not to the ruler, who will shortly emerge as a general without foresight, but to a young and innocent girl. Adopting the Aeschylean Eteocles' emphasis on the proper place for women, the Pedagogue is repeatedly scrupulous that no one in the city see Antigone making her momentary foray outdoors (89-95); the place for well-brought-up young women is at home (I93-20I). Here, however, Eteocles' stress on the internal safety of the city and the proper role of women in time of war is reduced to a fussy concern over the niceties of Athenian morality. In contrast, although Hector in Iliad 6 is similarly surprised to find his proper wife Andromache out of doors, Homer's magisterial Helen moves up to the wall for her teichoskopia in Iliad 3 with the freedom of a near goddess. The old men at the wall do not comment on her behavior but are so awed by her beauty that they think a war fought for Helen to be without blame (Iliad 3. I5658). 21

Antigone voices prayers comparable to that of Aeschylus' chorus and echoes their fear for the walls. She, too, is in terror of being captured in war. She prays, however, not in the apparently inappropriate manner of Aeschylus' chorus, but to gods whom a proper young virgin would invoke, Hecate and Artemis (I09-Io, I 5I-53, I90-92). Yet despite her use of the same excited dochmiacs and polysyllabic adjectives as Aeschylus' chorus of women (see the compound adjectives with leuko-, pan-, and chalko- in particular), 22 Antigone locks at the war from a different perspective. Aeschylus' chorus invades public places in terror of the ever-

\footnotetext{
${ }^{21}$ The scholiast on line 88 remarks on the sex/age reversal between this scene and the Iliadic teichoskopia, and on Antigone's inappropriate exit from the house later in the play.

22See Phoen. I I4, I I9, I20, I49, and Aesch. Seven i6o, Persians 4 I5, Suppliants 334 and numerous pan compounds. Parry 1978, esp. I67 and I73, argues that the mythohistorical odes of this play are Aeschylean yet deny the power of the past to shape the present.
} 


\section{Ritual Irony}

encroaching sounds of war. Euripides' Antigone is dazzled by the sunlit panorama that she sees from a safe distance (I I 7). ${ }^{23}$ Whereas Helen authoritatively identified the figures on the battlefield for Priam, the naive Antigone cannot interpret fully what she sees before her and has to be enlightened by the old Pedagogue. Tydeus' armor appears strange to the girl; the Pedagogue must explain that these arms are merely an Aetolian custom (I38-40). Whereas Helen cannot see her brothers, and ironically does not know that they are dead, Antigone sees her brother (ironically soon to be dead and united with her as she wishes, I63-67) 24 as a glorious but imprecise outline on the plain (I6I-62, I68-69).

The Euripidean battlefield acquires its epic brilliance less from the identification of well-known and bona fide heroes, as in Iliad 3, than from the subjective vision of an impressionable young girl. The Pedagogue's laconic statements undercut Antigone's questions and their glamorous expectations of battle. Yet Antigone's vision also domesticates the scene before her. The strange armor of Tydeus makes less impression than the fact that Antigone recognizes in him Polyneices' brother-in-law (132-38). Parthenopaius is a curly-haired young man with threatening eyes, a tame version of his ambiguous Aeschylean predecessor (I45-50). The orderly, circular progression of Antigone's survey of the battlefield and its terrain, as she picks out the heroes and remarks on their armor, does not uncover a significant relation between heroes and gates such as are found in Aeschylus. The scene becomes an epic-style digression that avoids hints about the future and thus does not contribute to developing a sense of tension and inevitability. The scene closes with the Pedagogue's rushing Antigone offstage to avoid an encounter with the arriving chorus, who he fears will be a source of gossip (philopsogon, I98) and confusion (taragmos, I96).

This expectation of trouble from the female, which was impor-

23Podlecki I 962 and Arthur I975: 44-46 note the emphasis on brightness in this scene. Barlow I97I: 57-60 stresses the subjective nature of the scene and the contrast between Antigone's innocent vision and the politics of the play, as well as the use of skiagraphia (a technique of contemporary painting), which suggests, along with the description of the images, that Antigone's knowledge of the world has come primarily from art.

${ }^{24} \mathrm{On}$ this point see Mastronarde I 974: $223 \mathrm{n}$. I6. 
tant to the characterization of Aeschylus' chorus, proves consistently irrelevant to Euripides' women in the Phoenissae. Euripides' foreign virgins proceed in measured trochees to evoke the peaceful world of Delphi, a world in which they are dedicated to dance and sing as a choros (236) for Apollo. This chorus, unlike Aeschylus' chorus of native-born women, is almost a chorus by profession. The women express a sympathy for Thebes based on a remote common ancestry (243-49) and on the journey they shared with Cadmus from Tyre to Thebes; but their hope is to extricate themselves from the present disaster in which they have been unwittingly trapped (237-38). They bring to the present situation a distanced and wide-ranging mythological perspective that includes not only the history but also the prehistory of Thebes. 25 Only in their final ode do they become involved in the action of the play to the point of adopting the anapests and dochmiacs of Antigone's teichoskopia and the dochmiacs of Aeschylus' first chorus in the Seven.

At this point in the play, then, the first two movements have gained at least part of their force from what seems to be a deliberate contrast with the literary tradition represented in Aeschylus' Seven and in epic. Jocasta has temporarily usurped the traditionally male role of rational concern for the city. Antigone takes on a role strikingly similar to that of Aeschylus' involved and native-born chorus but avoids its hysterical tone and its apparently inappropriate movement into external spaces barred to respectable women. This scene, Eteocles' later refusal to detail his battle plan, and the messenger's description of the actual battle ultimately give the conflict an open-ended, almost naturalistic quality. Epic is evoked,

\footnotetext{
${ }^{25}$ Whatever the complex reasons for Euripides' choice of this chorus, the combination of foreignness and remote kinship allows it to offer a wide-ranging perspective on the action. Rationalizations of Euripides' choice of a Phoenician chorus begin with the naive suggestion of a scholiast on Phoen. 202 that the chorus can speak more freely to rebuke Eteocles if it is composed of foreigners. Among many later views, Rawson I970: I I 2 (see also Goossens I962: 62 I) argues that Euripides has chosen an exotic chorus of Phoenician exiles as a deliberate contrast with Aeschylus' closely involved chorus. Rawson and Rebuffat I 972 find a further motive in recent Athenian relations with Carthage. Rebuffat argues that Menoeceus is sacrificed in a deliberately Phoenician fashion. Arthur I977: I66 views the Phoenician maidens as representatives of Thebes' literary past.
} 


\section{Ritual Irony}

as it is frequently elsewhere in the play, to offer a nontragic version of events. The Aeschylean moral drama about beleaguered Thebes and its arrogant and doomed besiegers fades through Antigone's impressionistic view and the parallel of the Iliadic teichoskopia, where the celebration of individual glory suppresses doubts about the rightness of the war. Indeed, the Pedagogue now pointedly attributes justice to the enemy (I54-55). The role of the teichoskopia has not fully emerged, however. For the Aeschylean parallel also prepares for Antigone's later role in the play when she, like Aeschylus' chorus, will rush immodestly into public spaces inappropriate to proper young women in order to help dissuade the brothers from their duel and to express her traditional concern with lamenting the brothers and the burial of Polyneices. Finally, Euripides' chorus of foreign women enters and, contrary to the expectations of the Pedagogue, expresses devotion both to the interests of the city and to the orderly performance of ritual and song.

A remarkably timid Polyneices now enters the city in terror of every sound (263-7I, especially 269), like Aeschylus' chorus. ${ }^{26}$ Just as Jocasta has assumed the role played by Aeschylus' Eteocles as the figure most concerned with the fate of the city, Polyneices now shares the perspective of the hysterical and endangered Aeschylean virgins. He expresses regret that he no longer belongs in the central spaces of the city that reared him (367-70). The characteristic reversal of roles continues. Men are now dangerous and antiheroic invaders of the central spaces of the city, whereas women soberly concern themselves with public issues. Aeschylus' Eteocles continually attempts to keep the enemy outside the walls, especially by the way he interprets their shields, and suppresses any internal surrender to emotion in time of war. ${ }^{27}$ In contrast, Euripides' Polyneices brings within the walls the dike he claimed on his shield in the Seven and tries with some success to establish his claim to that dike $\bar{e}$. Jocasta and her son stage an emotional re-

\footnotetext{
26The scholiasts on Phoen. 275 and 395 inaugurated a scholarly distaste for Polyneices' weak and unworthy character here. Schmid in Schmid and Stählin I $940: 580 \mathrm{n}$. 5 finds his entrance almost comic.

${ }^{27}$ On the important relation between inside and outside in the Seven, see esp. Bacon 1964 .
} 
union. Just as the Phoenician women have been deprived of the opportunity to dance in peace for Apollo at Delphi, the family quarrels have deprived Jocasta of her normal female role in presiding over the marriage of her son (344-49). She mourns in black for sons yet alive (322-26; Andromache in the Iliad similarly mourns for the living Hector), thus adding to the sense of political corruption in the city an image of ritual dislocation. But here again politics, not the women of Thebes, are primarily responsible for the disruption.

Eteocles enters second. The ensuing agon between the brothers delays, as he reminds us, Eteocles' Aeschylean role of marshaling the Thebans at the walls (448-5I; note, too, his haste to end the peace conference, marked by the transition to trochaic tetrameters at 588). 28 Jocasta domesticizes the debate by urging the brothers, as if they were unruly children, to look each other in the eyesafter all, they are not seeing a Gorgon's head (454-59). Jocasta soon exposes Polyneices' claims to justice as treason (569-85), but the ambitious Eteocles makes no claim to justice, arguing simply that no sane person would surrender or share the power that all men seek (499-525). After ignoring Jocasta's attempt at mediation, the brothers close their debate by deliberately choosing to destroy each other. Both will deploy their forces at the gates to ensure this meeting $(62 \mathrm{I}-22)$ :

$P$. Where will you set yourself before the walls?

$E$. Why do you ask me this?

$P$. So that I may station myself there to kill you.

E. Desire of this holds me also.

This expectation that the brothers will soon meet their fate is shortly to be disappointed, for they do not confront each other until after the battle.

Aeschylus' Seven derives its suspense entirely from the shield scene and from the increasing horror the audience feels as it becomes certain that brother will unwittingly be forced to meet brother in battle, thus fulfilling Oedipus' curse. Euripides' first

${ }^{28}$ Later Eteocles' haste turns his dialogue with Creon into rapid stichomythia. See Mastronarde I974: I 39. 


\section{Ritual Irony}

major scene has debased and domesticated the confrontation of the brothers. Supernatural forces play no obvious role in this conscious choice for self-destruction; the scene is hardly the centerpiece of the drama. The audience can only wonder, among other things, what tour de force will allow the plot to develop shape and moral significance. At the same time, the debate indirectly questions the premises of Aeschylus' shield scene. Aeschylus' Eteocles defeats the enemy first through language; by the end of the shield scene there is no need for an ensuing messenger speech to make it clear that Thebes will win and that the brothers will destroy each other. In the Seven the words of a good interpreter of signs have magical power, and Eteocles exercises that power through klédonomanteia, the power to read and interpret such signs. Whereas the shield scene of the Seven asserts a positive connection between sign and truth, language and reality, Euripides' Eteocles insists on the lack of connection, and Jocasta, who defends an Aeschylean position, fails to persuade her son.

Polyneices' claim to justice presumes that true argument is haplous (single and simple, 469) and needs no poikilon hermēneumatōn (subtle interpretations, 470), whereas the unjust argument, being sick, needs drugs $(47 \mathrm{I}-72) .29$ Jocasta, in undercutting Polyneices' claim to dike, essentially dismantles his insistence on a straightforward relation between his language and truth. Eteocles, on the other hand, argues that language is conventional: words do not mean the same for all, nothing is the same or equal for men except the name, and the fact implied by the name is not so (499502). Eteocles uses this argument to support his amoral claim to power. In her mediating argument Jocasta finds the principle of equality in nature as well as in cities or in the minds of different men $(535-48)$. That is, for Jocasta language has a basis in reality itself. The isotês (equality) for which she argues, as many scholars have shown, has its origins in pre-socratic concepts that equate the

${ }^{29}$ For discussion of the rhetoric of the speeches of the brothers, see esp. Mastronarde I974: Iooff. and Arthur I 975: I04-I3. Polyneices' speech has a rhetorical correctness lacking in Eteocles'. For Polyneices' claim about language, see Aesch. Hoplōn Krisis frag. I $76 \mathrm{~N}$ : hapla gar esti tēs alētheias epē. 


\section{The Phoenissae}

political and the natural and, as Heraclitus shows, in language itself, for both nature and language exist through logos. 30

Jocasta's rhetoric rationalizes Eteocles' celebration of the myth of autochthony in the Seven: against the arrogant, impious, and unjust Argives stands gate by gate a series of sown men as devoted to their mother earth as they are virtually indistinguishable. In asserting that mortals have no private possessions but care merely for those of the gods, Jocasta also echoes the egalitarian arguments of Solon and other Athenian statesmen, both sophistic and presophistic, and thereby reconciles myth and logos, the traditions of autochthony and contemporary scientific arguments for equality and against tyranny (although Sophists such as Thrasymachus in Plato's Republic argue that tyranny is "natural"). Her position defends the principles upon which both Aeschylus' Thebans and Euripides' Menoeceus die. She fails to persuade her sons; and she even puts her own argument in partial jeopardy by suggesting that some words, such as to pleon (profit), have onoma ... monon (a name only, 553). The brothers leave the stage after some wordplay on the name of Polyneices, "the man of many quarrels" (636-37), which, in the context of their openly unfraternal quarrel and their professed views of language, further undercuts the possibility that words can determine reality in this play.

Although Euripides has apparently made an Aeschylean shield scene impossible by Antigone's teichoskopia, by the brothers' deliberate and outrageous choice to destroy each other, and by Eteocles' attack on the relation between sign and reality, the following scene continues to tease the audience with the possibility that the deployment of the warriors at the seven gates may yet gain some novel significance. In this scene Eteocles, apparently forgetting his promise to meet his brother at a gate, considers several alternative military strategies (7I 2-34). The blatant anachronism of these suggestions, which all derive from fifth-century warfare, serves to underline the deviation from tradition. Creon has to persuade the

${ }^{30}$ For discussion and references, see Arthur I975: I I 3-I 7 and Mastronarde 1974: I03ff. For a brief reference to the views of language in the passage, see Pucci i 980 : $80-82$. 


\section{Ritual Irony}

hasty and imprudent ruler, so different from his competent Aeschylean counterpart, to adopt the Aeschylean strategy (73756). 31 Finally, as Eteocles prepares to leave the stage he curtly refuses to waste time with a description of the deployment of the warriors at the gates, a description that would evoke the Aeschylean shield scene in the minds of the audience $(748-52)$ :

These things will be. Going to the seven-gated city I will arrange the captains at the gates, as you suggested, matching our citizens with equal opponents. It is a waste of time to give the name of each captain, since the enemy is encamped beneath our very walls.

But Eteocles does not simply refuse to play the role of his Aeschylean counterpart. He temporarily usurps functions performed by others in Aeschylus' Seven and in Sophocles' Antigone, and performed after rather than before the battle: he leaves instructions concerning his own and Polyneices' burial, Antigone's marriage with Haimon, Creon's role as ruler, and his father, Oedipus (757-77). (The later Oedipus at Colonus follows Euripides in having Polyneices request burial before the battle.) Unlike his Aeschylean counterpart, Eteocles cannot resist concern with the oikeia, his private interests, as well as with, or even over, the koina (common interests, 692). Although the dividing line between public and private interests is always difficult to establish in the case of a royal house, Euripides' Eteocles makes a point of separating these interests and hence draws attention to the clash between public and private that was developed earlier in the agōn with Polyneices. Indeed, the ironic disparity between his present concern for family matters and his earlier willingness to "let the whole house go to ruin" (erretō propas domos, 624) is patent. At his departure for battle Eteocles again remembers his hope to meet his brother face to face-but this time, although no lots have been cast as in Aeschylus,

\footnotetext{
${ }^{31}$ See Garlan 1966 for parallels between fifth-century military tactics and Eteocles' suggestions here (see also Goossens 1962: 617). Garlan sees in this scene and the battle scene a close parallel to the military dilemma presented by Agis of Sparta when he approached the walls of Athens in $4 \mathrm{II}$ and $4 \mathrm{IO}$. The Athenians chose passive defense of their ramparts rather than active defense of the surrounding territory. Depending on the date of the play, Euripides is either commending the city's prudence in $4 \mathrm{I}$ I or warning her to restrain her bellicosity after $4 \mathrm{IO}$.
} 


\section{The Phoenissae}

he hopes that chance will offer him this opportunity (moi genoito, 754; see also 755). Like Aeschylus' Eteocles, he calls for his armor, although he does not, as Aeschylus' Eteocles probably did, arm onstage (778-8I). In the Seven, the call for arms emphasizes the sudden transformation of the hero into a warrior irrevocably set on the killing of his brother. In the Phoenissae, the armor is a useless prop, another red herring whose significance cannot be fully appreciated without a knowledge of the Aeschylean text. 32 Eteocles hopes to depart with dikēi nikêphorōi (justice that brings victory, $78 \mathrm{I}$ ); here, if the text is correct, 33 he lays claim to a virtue to which he, unlike Aeschylus' Eteocles, has earlier admitted he had no right.

Finally, Eteocles leaves to Creon the confrontation with Apollo's representative Tiresias, whereas in other known Theban plays (Sophocles' Antigone and Oedipus Rex, Euripides' later Bacchae) the patriotic ruler undertakes it himself. Eteocles calls attention to this deviation from dramatic tradition by remarking that, because of previous bad relations between himself and the seer, he fears that Tiresias might refuse to deal with him (772-73). In the following scene Creon, faced with the sacrifice of Menoeceus, then readily abandons his equally traditional role as advocate of the claims of the state over those of family. Eteocles leaves the stage without knowing, in the sense that only the gods can offer true knowledge, how to save the city. ${ }^{34}$ The scene between Creon and Eteocles thus unfolds entirely as a series of lightning-fast rejections or usurpations of the roles played by Theban rulers in times of crisis in the plays of Aeschylus, Sophocles, and, no doubt, others. Zeitlin, in a discussion of Euripides' Orestes, argues that Orestes borrows frantically from a "closet of masks" belonging to characters in earlier poetry and drama. 35 Through these masks Orestes tries at one moment to escape from his myth, at another to replay familiar roles in a world that has rejected them and whose culture is frag-

${ }^{32} \mathrm{On}$ the arming of Eteocles in the Seven, see Schadewaldt I96I. For further discussion with bibliography, see Taplin I977: I 58-6I, who disputes Schadewalt's previously accepted views.

${ }^{33}$ This line may be interpolated, since it is missing in a papyrus fragment. See Haslam 1976: 7-8.

${ }^{34}$ See Mastronarde I974: 194.

${ }^{35}$ See Zeitlin 1980. 


\section{Ritual Irony}

mented beyond the point of recovery. The process expresses the hero's crisis of identity in a world without paternal role models.

Euripides' Eteocles in undoubtedly also a volatile personality, but the similar raid on the "closet of masks" in the Phoenissae serves a different end. The deliberate perversion of traditional roles undertaken by the brothers distracts the audience from any mounting concern for their nature and welfare as individuals and calls attention instead to an erratic development of the plot, an emerging sense of ritual dislocation, a pattern of inversion and transformation of male and female roles, and a pervasive split between public and private concerns. Without myth, without divine pattern, without the claim of language to mirror reality, Euripides' tragic poetry threatens to descend from the realm of philosophy, where necessary and probable events cohere in a well-selected praxis, to the randomness of history (see Aristotle's contrast between poetry and history at Poetics I45I Ib). Indeed, as Tiresias will shortly confirm, Eteocles' inadequate leadership puts Thebes on the brink of an antimythical disaster and thus creates the necessity for Menoeceus' intervention.

In fact Eteocles' promise of a battle between the seven pairs of champions with their squadrons $(749-50)$ is never fulfilled. The arrangement of gates and shields is reported by a messenger after the battle, and at surprising length, given Eteocles' earlier scorn for the enterprise. Aeschylus' famous kledonomantic ritual between ruler and scout, in which the language and action of the ruler shape the ensuing battle, becomes in the messenger's account an almost exclusively naturalistic encounter between the two armies. 36 Eteocles, in the course of a military encounter that essentially ends in a

\footnotetext{
${ }^{36}$ For a defense of the battle scene, many parts of which have been excised by textual critics, see Mastronarde I 978 and Mellon I974: I 52-54. Mellon argues that the shield scene does not repeat the teichoskopia, that it satisfies the audience's expectations for the Aeschylean scene, and that Euripides wishes to separate this static description from the narrative that follows. Adopting these arguments as well, Mastronarde comments on how the shield scene orients the audience pictorially for the following action (an orientation made nearly impossible by the omission of these lines) and defends the artistic value of the text for its relation to the saf ety of the city theme in the play. He stresses that neither the possibly parodic relation of this passage to Aeschylus nor a few textual obscurities argue for interpolation in a passage that Page I934: 2 I admits to be written in a generally Euripidean style.
} 


\section{The Phoenissae}

draw, moves from gate to gate (I I63-7I), never directly confronting Polyneices. 37

Although we know little about epic treatments of the battle of the Seven, we do know that in the Thebaid there were, as here, two phases to the battle rather than one as in Aeschylus. The first included the attack on the city, the death of Capaneus, and the single combat between the sons of Oedipus; the second, the battle between the remaining champions and the victorious sortie of the Thebans. 38 Yet as in later versions, the fraternal duel belongs to the first phase. Euripides apparently also draws on epic tradition in his choice of the name Periclymenus (I I 57), the one Theban champion mentioned besides Eteocles, and in his selection of Adrastus rather than the Aeschylean Eteoclus, Eteocles' near double in name, to represent the enemy. ${ }^{39}$ Perhaps the poet, in preparation for the role of Menoeceus, deliberately avoids the mention of Aeschylus' autochthonous Theban champions and makes a point of separating the fate of Thebes from the duel of the brothers reported in the second messenger speech. ${ }^{40}$ The messenger's report has minimal and cryptic correspondences with the Aeschylean shield scene. Tydeus' shield with its fire-bearing Prometheus (I I2O-22) recalls that of Aeschylus' Capaneus, which shows an unarmed man bearing fire to burn the city. The giant portrayed on Capaneus' shield may invite remembrance of the immense size of Aeschylus' champion of the same name (I I I I-32), and his hubristic challenge to Zeus' thunderbolt as he mounts the walls of Thebes conflates the images represented on the shields of Aeschylus' Capaneus and Eteoclus (I I 7276). If anything, the comparison with Aeschylus' Capaneus functions to divert attention from the symbolic power of the image on the shield to the diminished threat of Euripides' champion. Adrastus' child-snatching Hydra (I I 35-38) recalls Parthenopaius' Cadmean-bearing Sphinx in the Seven; yet the Hydra, unlike the Sphinx, has no special meaning in the Theban context. The only

\footnotetext{
${ }^{37}$ On the relation between gates and warriors in the Seven, see Zeitlin I982.

${ }^{38}$ For a discussion of the Thebaid battle, see Vian I963: 203. For epic coloring to the language at I067-I283 and its effects, see Barlow I97I: 73 n. 46 and ro6 and Arthur 1975: I34-39.

${ }^{39}$ See Zeitlin I 982: 73-82 on Eteocles and Eteoclus.

${ }^{40}$ See de Romilly i 967 : i 5 on this second point.
} 


\section{Ritual Irony}

shield identical to those described in the Seven is that of Amphiareus (IIII-I2), and it is a blank one.

Attempts to interpret Euripides' description of warriors, gates, and shields as symbolic have been notably unsuccessful, and the lack of significant pattern becomes a statement in itself. Individual shields may hint at a possible message. The horses on Polyneices' shield, the mares of Potniae who ate their master (I I 24-27), suggest civil strife and contrast with the controlled steeds of Amphiareus in the teichoskopia (I7I-74) or of Eteoclus in the Seven (46I-64).41 Capaneus' boast and the figures on several Argive shields-the earthborn giant Argus, the Hydra, and the fire-bearing Prometheus-meet an appropriate defeat from the thunderbolt of Zeus. Yet the enemy makes no consistent challenge to the gods. Parthenopaius' neutral blazon shows his mother Atalanta heroically defeating the boar. The choral odes before the messenger's description of the battle scene have prepared for such ambiguity by emphasizing the presence of monsters within, not merely outside, the city, and Eteocles has made it clear that justice is no longer claimed by the Theban side. Hence Zeus himself must intervene to establish a distinction between friend and enemy, inside and outside, made in Aeschylus' version by Eteocles himself as he sets Hyperbius' blazon of Zeus and his thunderbolt against the challenger Hippomedon's hubristic image of a fire-breathing Typho. Whatever hints the messenger's speech provides, the speech as a whole remains as teasingly inconclusive and unreadable as Amphiareus' blank shield. As in the agōn between the brothers, the relation between signifier and signified and between image and reality remains opaque or purely fortuitous. If Euripides is borrowing here from epic versions of the scene, the choice, as in the teichoskopia, is not a neutral one, but a deliberate effort to avoid the tragic implications of the scene offered by Aeschylus. The effect is to highlight the decisive external intervention of the thunderbolt of Zeus, the presumed mark of Menoeceus' sacrifice upon an action that threatens to take an arbitrary and antimythical course.

\footnotetext{
${ }^{41}$ On the horses, see Mastronarde I974: I99, de Romilly i 967: I I0, and Arthur I975. Arthur argues ( $132-34)$ that through the shield devices the assault on the city becomes civil strife (the mares of Potniae turned savage and ate their master Glaucus), and that the shield devices resonate with the dragon theme of the choral odes.
} 


\section{The Phoenissae}

The return of Eteocles' squire as a messenger after the battle might at first suggest to the audience that Eteocles is dead. In fact only some time after the messenger speech is there any account of the expected fatal meeting between the brothers. Having failed to fulfill their promise to meet each other and thereby carry out their father's curse during the battle, they have belatedly chosen to confront each other in a duel. 42

In Aeschylus, Eteocles' decision to meet his brother at the seventh gate stirs horror in the chorus of women and a deep fear that fraternal blood will pollute the land of Thebes. In Euripides' Phoenissae the armies ratify their leaders' decision (I238-39); they are only briefly touched by shock at the fraternal encounter (I369-7I, if these lines are genuine), which evokes horror in the family only. There is contrast, too, for example, between his army's advice to Polyneices to set up a trophy of victory to Zeus (I250-52) and Jocasta's earlier reproach to her son at 57I-72: "What trophies can you dedicate to Zeus?" No one mentions pollution; Oedipus' curse is forgotten. Indeed, the duel scene is dominated by the enthusiastic partisanship of each army for its respective champion and unfolds with all the formal features of an epic duel, including a Homeric simile $(1380-8 I)$. Duels in Euripides proceed as they do in the Iliad:43 the arming of the warriors is followed by a prayer, the encounter is often decorated by a simile, and the contest unfolds in a sequence of confrontations involving spear, stone, and sword. The setting is usually a truce between the two armies. Extant epic duels are inconclusive, failing through treachery or divine intervention to settle the issue for which they were undertaken. Here the duel is inconclusive (I 424, I460-79) not because death is forestalled, but because both brothers die. As in epic, the duel serves as a prelude to another battle, here won by the Thebans only because promethia led them to retain their arms as they watched the contest ( $1466-72)$. Both Eteocles' use of trickery (the

\footnotetext{
42Von Fritz 1962: 209 argues that the duel of the brothers is now unnecessary, since the city has apparently already been saved. Hence we cannot, with Reimschneider 1940: $38 \mathrm{ff}$., fully def end Eteocles for his proposal of the duel on patriotic grounds, or sentimentalize his death with Treves I930: I 87. If the brothers had not completed their duel, however, Oedipus' curse would have remained unfulfilled, and the play would have concluded in an antimythical fashion.

${ }^{43}$ On the challenge to single combat, see Mellon i974: I54-56. On the epic quality of the duel, see Arthur I975: I 34 .
} 


\section{Ritual Irony}

Thessalian sophisma at I407-8) and the Thebans' wearing of arms during a truce discredit the city and deprive its victory of a moral dimension. The duel is terminated not by superior strength or skill, but by Eteocles' own greedy restlessness to despoil his brother (I 4 I6-24); and the brothers' final expressions of familial sentiment toward Jocasta and Antigone make no amends for their previous self-serving attitudes but simply create new and dangerous responsibilities for their sheltered sister. To an audience familiar with tragic versions of the confrontation between the brothers, the almost morally neutral (as in epic?) treatment of the fratricide must have seemed striking and perhaps even shocking. Because Homeric duels end inconclusively, the tragic outcome to the duel of the brothers in Euripides has an unexpected quality, as if a tragic resolution is finally being imposed on a conflict that has long threatened to delay or even preclude its traditional outcome.

In the final scenes Oedipus' late banishment offers yet another opportunity for bringing several aspects of the literary tradition into conflict. Antigone cannot both accompany her father into exile and pay the penalty for the burial of her brother. Lines I66682 make it clear that she abandons her resolve to bury Polyneices, for the bodies of both brothers are onstage well guarded by Creon and then almost certainly removed by him; her change of mind in the final lyrics concerning the burial is probably spurious. ${ }^{44}$ Creon offers no reason for his denial of burial to Polyneices except the command of Eteocles, who was acting out of hatred for his brother. As in the case of Creon's unnecessary exile of Oedipus, a Sophoclean patriotism is suspect from a man willing to abandon

\footnotetext{
${ }^{44}$ Lines $1743-46$ have been condemned by nearly all commentators. Antigone is unlikely to have reversed her decision without explanation in the final lyrics (as opposed to iambics). The interpolation may reflect a resistance to abandoning the burial of Polyneices by Antigone or, as in the case of some later commentators, a failure to understand that Creon has forced Antigone to give up her original intentions. No defender of these lines can explain how Antigone could accomplish her plan, given Creon's superior power and his knowledge of her intent. Abandonment of the burial motif is shocking but not entirely surprising from a poet who was capable in his own Antigone of allowing Haimon to rescue Antigone and have a son by her. For a good discussion, see Conacher 1967b, esp. 98-99, who replies effectively to Meredith 1937 and Kitto I939. My interpretation of the role of Antigone would be the same if the text were genuine, however. Aeschylus, too, if the ending of the Seven is genuine, leaves the burial issue unresolved.
} 
the city to save his son Menoeceus, and even his loyalty to kin is ultimately limited in every case to his own immediate family. Thebes remains indifferent to the religious issues involved in Polyneices' burial, and Antigone can pursue her commitment to kin only in exile. Despite the uncertain text, 45 the final scene apparently provides Antigone an opportunity to compensate for her failure to live out her by now familiar role. We shall examine later her heroic affirmation of loyalty to Oedipus.

${ }^{45}$ Critics have found numerous inconsistencies, interpolations, and textual difficulties in the exodus of the play (I $582-1766)$. Important discussions, in addition to those in the commentaries, can be found in Wilamowitz I903, Friedrich 1939, Kitto I939, Valgiglio 1961, Fraenkel 1963, Diller 1964, Erbse i966, Conacher I 967b, Mastronarde I974, and Mellon 1974. Erbse and Meredith I937 alone defend the entire exodus, including I737-66. The following major features have disturbed commentators: Creon's silence from I $356-$ I 584 , his abrupt exit, and his failure to give explicit commands concerning the disposal of the bodies; Oedipus' dull and confused rhēsis at I595-I624 (see note 5I below); Oedipus' trochaic tetrameters at 1758-63 (clearly borrowed from Sophocles' OT); and Euripides' inclusion of the conflicting motifs of exile and burial (see note 44 above). I agree with critics who def end the exodus as genuinely Euripidean. Those who wish to eliminate one of the two motifs, burial or exile, must excise large parts of the earlier text, which clearly prepares for an appearance by Oedipus and an expanded role for Antigone. On this point, see esp. Conacher r $967 \mathrm{~b}$ : 94-95 and Mastronarde 1974: 227-36 and 522. There are dramatic precedents for Creon's long silence, and his abrupt departure poses few difficulties. His business is finished, and his major motive throughout has been an overriding concern for his sons. (See Robert I9I5: I, 444 on Creon's motives, and Mastronarde I974: 494-500 on Creon's role in the exodus.)

I remain uncertain about the final lyrics from $1737-66$, with the exception of I743-46 (see note 44 above), which should almost definitely be deleted. The absence of these lines from the Strasbourg papyrus, which quotes the rest of the lyrics, is certainly damning. Obscurities in the text from I 747 to 1757 do not necessarily argue against these lines; as Meredith I937: IO I says, "Genuine interpolation may be platitudinous, bathetic, or frankly absurd: it is not usually $o b$ scure." The dialogue between Antigone and Oedipus does not contradict the exile motif; it simply reintroduces Oedipus' hesitation to accept Antigone's company in exile and reasserts the importance of the maiden's role in ritual and religion, a major theme in the play. These lines effectively divide Antigone forever from the world of the Phoenician maidens of the chorus (see my later discussion). The final lines of the chorus do remarkably break dramatic illusion in their request for victory. And Oedipus' trochees, though it has been argued that they make an effective parody of Sophocles in a play riddled with such allusions, are awkward both because they address an imaginary Thebes and because Oedipus insists on reintroducing the Sphinx issue closed by Antigone at I732. Other characters in tragedy make apostrophes to invisible audiences, however (see Mellon I974: I 48 n. 4), and Oedipus is an eccentric character throughout the exodus. 


\section{Ritual Irony}

Euripides' allusions, designed inconsistencies, and red herrings baffle expectations for the outcome prescribed by myth. ${ }^{46}$ The allusions to epic apparently further emphasize Euripides' refusal to adopt previous known tragic interpretations of the myth. Each scene, though it may have internal coherence, has an oblique or indecipherable relation to the last: Polyneices and Eteocles agree fairly early to meet face to face in battle but fail to do so until much later; Eteocles adopts the Aeschylean strategy of placing seven warriors at seven gates, then fails to remain at one gate; Eteocles refuses to provide a shield scene, but a messenger later fills the gap. The bizarre redundancies and inconsistencies in the action, excised by generations of philologists, appear to be part of a deliberate and comprehensive iconoclastic strategy. Polyneices alone claims justice; Eteocles refuses to meet Tiresias; the brothers delay their duel; and Creon, whose patriotism is continually made suspect, apparently shockingly succeeds in preventing Antigone from burying her brother. This persistent devotion to narrow interests challenges the mythical tradition, which ensured the survival of Thebes and the extirpation of the house of Laius. The gestures of Jocasta and Antigone do not affect the public world, which scarcely notes the sacrifice of Menoeceus. Thus the play's failure finally to resolve the expected tragic tensions between religion and politics, male and female, and family and state seems not so much inevitable as the result of deliberate neglect. Like the adikos logos (unjust argument) described by Polyneices (470-72), Euripides' plot seems in need of subtle drugs and a sophisticated hermeneutics.

\section{The Effect of Menoeceus' Sacrifice on the Action}

By the end of the play, the plot has in fact largely achieved not only the conclusion represented in the tradition adopted by Aeschylus, but also the precise axial symmetry or ring composition

\footnotetext{
${ }^{46}$ For Euripides' tendency to break out of the limits of traditional myth, see esp. Zeitlin I980. See also Goffmann I974, esp. $345-77$, on the technique of "breaking the frame."
} 
identified by Ludwig. The action opens and closes with family concerns; the debate of the brothers is matched symmetrically by their fatal duel; and the central moment is the death of Menoeceus, heightened and framed by a concentration of choral odes. In this sacrifice divine command and human action coincide, as they initially fail to do elsewhere in the action. In terms of the Aeschylean plot, the intervention of Menoeceus offers a temporary substitute both for the death of the brothers and for Eteocles' ritualized deployment of the Spartoi against the enemy. ${ }^{47}$ Here, however, only one sown man is singled out from Aeschylus' nation of autochthonous warriors to devote himself consciously to his mother earth. If Menoeceus' sacrifice was, as most scholars think, a Euripidean addition to the myth, in the Phoenissae Thebes is "saved" through the poet's intervention. The death of Menoeceus is indeed, as Tiresias characterized it, a pharmakon (893), a cure that salvages a plot in which the characters are, as Oedipus was said to be when he cursed his sons, sick (66), or unable or unwilling to listen to a divine voice. Tiresias refuses to speak directly to Eteocles, and Creon refuses until after the battle to follow his advice (9I9). Even if Euripides did not invent the character of Menoeceus, he has designed his role so that it appears to be an external intervention, a true méchanē sōtèrias (a way of providing safety, 890, like the god on the méchane or machine) to save a Thebes that would otherwise have fallen, against tradition, to its enemies.

In other plays involving a voluntary sacrifice, the community that is to benefit from the sacrifice performs it in response to a supernatural command. Here the sacrifice does come, as in Girard's model, as a resolution to a social crisis in which the characters, like the leaders of Thebes in this play, have descended into "mimetic rivalry." Creon, fearing precisely this kind of communal demand for the sacrifice (970) should the people hear of Tiresias' prophecy, tries to send Menoeceus into exile, thus blocking a Girardian solution to the social crisis of the play that is almost enacted in Euripides' later Iphigenia in Aulis. Indeed, in the version of the tradition given by Apollodorus (3.6.7), Tiresias gives the

\footnotetext{
${ }^{47} \mathrm{On}$ previous views concerning Menoeceus' sacrifice, see notes I-3 and I6 above.
} 


\section{Ritual Irony}

oracle to the Thebans rather than to Creon and requests a voluntary sacrifice before the gates. As a result Menoeceus' self-sacrifice, an act of deception against his father, is accomplished in complete and extraordinary isolation from the community. Not only do we know that in other plays a youthful sacrifice is in essence a communal ritual; in addition, in the Phoenissae Tiresias enters with an allusion to his role in Euripides' own earlier play, the Erechtheus, in which Praxithea volunteered to sacrifice her daughter to save Athens $(852-57)$. The reference to the earlier play serves mainly to underline the unusual and distorted pattern to the sacrificial action here. 48 The Thebes of this play is a world that fails to perform its own sacrificial cure and hardly recognizes Menoeceus' gesture when it occurs.

Sacrifice, as was argued in Chapter $\mathrm{I}$, is an act of communication between god and man. It is also an act that defines a political community. Only citizens participate in the act and share, on preestablished principles of distribution, in its benefits. In so doing citizens give and share in a gift that is no longer their own, but the gods'; by participating in sacrifice they tacitly indicate their submission to the community, its rules, and its hierarchies. Thucydides compares the relation of citizens to their city with that of guests at an eranos, a collective meal at which each guest brings a share (2.43). ${ }^{49}$ Jocasta and Menoeceus envision the relation of men to wealth, political power, and community on principles that precisely echo this model of sacrifice; a man's life and wealth belong to the city and the gods (555-67, IOI5-I8). Ideally, sacrifice is organized to conform with both the religious and political organization of the community and enacts the unity between the two realms. As is emphasized in Jocasta's inability to preside at her exiled son's wedding, her mourning garb at the agōn between the brothers, and the failure to bury Polyneices, ritual in the Phoenissae

48Vellacott 1975: 195-98 finds the reference to the Erectheus ironic: the sacrifice in that play offers ambiguous help to the country, three daughters (his sole heirs) die instead of one, and Erectheus is engulfed in a chasm. The conclusion thus casts doubt on Praxithea's original patriotic speech (very similar to that of Menoeceus in this play) and atypical willingness to sacrifice her child.

${ }^{49}$ For a discussion of these issues in the play and parallels with Thucydides, see de Romilly i 967. 
is severed from its proper relation to the community, even while Menoeceus' gesture miraculously preserves it.

Positive deceptions performed in a ritual context are not unusual in Euripides. In the Iphigenia in Tauris, Orestes and Iphigenia use the cult of human sacrifice dedicated to Artemis to escape their terrible past and to bring back to Greece a cult of Artemis in which human sacrifice is only a memory; here the plot explicitly declares inadequate the conclusion offered by Aeschylus' Oresteia (IT 96I75) and provides a novel solution to the dilemmas faced by the house of Atreus. In both the IT and the Phoenissae the sacrificial rite becomes a source of healing. What appears to be a deviation, an arbitrary intervention, or an addition to an already completed myth is in fact the origin of salvation. Yet in the earlier play Orestes and Iphigenia recreate a sense of community through their ritual deception, whereas Menoeceus' secret gesture emphasizes his estrangement from his fellow men.

Menoeceus' action substitutes for the deus ex machina traditional in late Euripidean drama. Yet, because it comes in the middle of the play and not at the end, the audience experiences simultaneously the return of the myth to its traditional course and the seemingly marginal effects of the sacrifice on the politics of Thebes. As the deliberate actions of the characters finally begin, as in most Greek tragedy, to serve rather than undermine a tragic pattern, traditional material willfully abandoned in the earlier scenes surprisingly reappears in a new context. The messenger follows his mention of Menoeceus' sacrifice with the shield scene earlier rejected by Eteocles; Eteocles, in proposing the duel with Polyneices, offers for the first time patriotic motives for his belated action (I223-35). Creon, however questionable his motives, finally assumes his traditional stance as city defender in banishing Oedipus and in refusing burial to Polyneices. Antigone emerges from seclusion to attempt the full roster of roles offered her by tradition as well as to undertake with Jocasta the mediating role of Aeschylus' chorus. Yet none of the characters seems to act in direct response to Menoeceus' gesture; we do not even know whether the brothers know of it. And, as if to emphasize the incurable state of Theban politics, Euripides closes the play with the denial of burial to Polyneices and a departure to survivalin exile. The difficulty of locating precisely the effects of the 


\section{Ritual Irony}

sacrifice on the action has led some scholars to argue that the myth finally reaches its expected conclusion by strictly human means. 50 Yet tragedy never represents human actors as puppets of the divine, and the fulfillment of a divine pattern is perceived only after it has been achieved. Oedipus, if all his lines are genuine, closes the play by recognizing at some length the role played by divine forces in his life. 51 Tiresias' prophecy, the thunderbolt of Zeus, and the central placement of the Menoeceus episode in a plot in which the characters have previously threatened to escape their fate seem to argue for the power of Menoeceus' sacrifice to redirect, however mysteriously, the action to its mythical tradition.

\section{Menoeceus' Sacrifice and the Choral Odes}

Menoeceus' choice to sacrifice himself establishes the single point of intersection between the song cycle of the chorus in the first four odes and the action of the play. As Menoeceus enters the action of the play he also steps out of the action and into a separate world established by the choral odes and by Tiresias' divine command, a world that offers a coherent interpretation of his sacrifice. From this perspective, Menoeceus' autochthonous heroism as the last pure sown man atones for the violence done to the earth-born dragon at Dirce, where Cadmus, seeking water for the sacrifice of a heifer, encountered and killed the monster with the help of Athena. Ares, god of war, and Earth, who bore the sown men, both demand a reparation for this crime. Menoeceus' sacrifice must be understood in relation to the act that founded Thebes and to the pattern of its entire history, which unfolds as a series of violent confrontations between the rulers of Thebes, Cadmus and Oedipus, and a series of mythical monsters that are defeated with the nelp of divine interven-

50 See notes 12 and 42 above.

${ }^{51}$ The genuineness of all or part of Oedipus' rhèsis at I 595-I 624 has been questioned on grounds of textual difficulties and style. But Oedipus' speech is apparently meant to be a subjective interpretation of his experience by an old man confined to years of silence and obscurity within the palace. For a sympathetic treatment of this speech, see Mastronarde I974: 525-26, despite the textual difficulties discussed at 526ff.; Mellon I974: I 28-33; and Meredith I939, esp. I00-IO5. 
tions. The battle between the brothers reenacts that of the Spartoi, and Oedipus' defeat of the Sphinx contrasts with Menoeceus' surrender to the dragon. As Arthur has argued in the most recent and detailed treatment of the song cycle of the odes, the lyrics offer an interpretation of the chronicle of Thebes, moving gradually from prehistory to the present, juxtaposing past and present events, and discovering significant patterns and parallels between apparently unrelated actions. 52 After Menoeceus' death, however, the women of the chorus lose their foreignness and their detachment and become absorbed into the action of the play.

The Phoenician women describe themselves as offerings (akrothinia, 203; see 2I4-I5) dedicated to Apollo and hence attuned to the language of their god; they anticipate and echo the perspective of Apollo's seer Tiresias and the sacrificial role of Menoeceus. Throughout the odes a structural contrast is developed between the Apolline world at Delphi and the peaceful era of Thebes' prehistory, on the one hand, and the world of Ares at Thebes, the world in which the chorus is now trapped, on the other. The maidens open the parodos by evoking a vision of the world to which they intend to go at Delphi, a world of music, dance, and perpetual celebration where they will wet their hair with pure water and serve their god in an environment of light (222-25). There Dionysus is tamed and earth-born dragons are destroyed; nature, god, and man live and act in apparent harmony (226-38, $645-75)$. Early Thebes is also idealized. The walls of the city rose to the music of Amphion's lyre; Cadmus married the divine Harmonia, or the principle of social unity, at a wedding attended and blessed by the gods. ${ }^{53}$ Earth gave forth water and fruit to the city,

\footnotetext{
52See Arthur 1972. My discussion owes much to her argument and is therefore briefer than it would have been otherwise. Arthur's general thesis is that the odes provide the link between the themes of fatherland and family, between the heroics of the past and the present disgrace (I64). The odes develop the theme of the curse of civilization that orders and controls all the major action of the drama (I74); the play is pessimistic, for violence is incorporated into the founding of the city itself (I84-85), and the defenders of the city are also its destroyers (I82). Order and chaos reach rapprochement only in the environment of ritual control at Delphi (I69). Parry I978: I66-73, esp. I67, argues that since the action is so remorselessly focused on realpolitik, the odes polarize as much as synthesize the different temporal dimensions of the play and what they represent.
}

53See Vian I963: I 42-43. 
and the maidens of Thebes once danced for a Dionysus apparently untainted by the violent elements of his myth that we know from the Bacchae. Even the mention of Semele's death by the thunderbolt of Zeus is here suppressed. Menoeceus' sacrifice finds a place in this world made by and for the beautiful dances of maidens, a world of ritual activity and poetic permanence in which violence is repressed or given meaning as part of a divinely inspired order.

In contrast, the world of Ares in which the chorus currently finds itself, and in which Thebes was previously caught during the attack of the Sphinx, is repeatedly called unmusical (785, 79I, 807, I028), unproductive of happy maiden songs and dance, and productive of lament $(784-800$, I033-42). 54 The city, founded at a terrible price, always threatens to regress to the mutual slaughter or the volatile aspects of autochthony enacted in the original battle of the sown men (80I-I7, I296-98). The sown men are for the city a kalliston oneidos (82 I), a brilliant reproach, a source of glory and safety for Thebes in war and a threat to its internal equilibrium. The land of Thebes itself also persistently threatens to avenge the violation of the earth accomplished at its origin. The chorus, then, offers a vision of the city's history unique among extant Theban tragedies; the city is portrayed as having been founded on a unity of opposites, on a tension between violence and harmony, to which two kinds of dance and song and ritual performances respond. Delphi offers ritual control of violence like that represented in the sacrifice of Menoeceus, whereas the world of Ares represents the uncontrolled mimetic competition of the political world. The problems of the Labdacids are absorbed into a larger picture of the history of the city itself; the chorus, whose journey has repeated that of the founder Cadmus to Thebes, broadens the relation of the present to the past.

Aeschylus' chorus of native women enters the action of the Seven to try to prevent Eteocles from fighting his brother, and then to lament the bodies of the two brothers, perhaps accompanied by Antigone and Ismene. At precisely the same moment in the action of the Phoenissae, when the messenger brings the news

${ }^{54} \mathrm{On}$ the theme of distorted dance and song in the play, see especially Podlecki I 962, esp. 369-72, and Arthur 1975: 52-53. 
of the impending duel between the brothers (but after the death of Menoeceus), the chorus finally adopts the anapests and dochmiacs of Antigone's teichoskopia and the dochmiacs of Aeschylus' opening chorus and begins to share directly the fears of Antigone and Jocasta (I284-I306). Antigone and Jocasta then assume the role of Aeschylus' chorus, attempting to dissuade the brothers from their duel, and the Phoenician maidens relapse into silence. They do not fulfill their promise to lament the brothers (I3OI-2), for their Aeschylean role has been usurped by Antigone and Oedipus. 55 Euripides' chorus seems to function to provide an alternative lyric perspective on the action and especially on the sacrifice of Menoeceus. The chorus becomes silent precisely at the moment when, as a result of Menoeceus' death, the action begins to move back toward the tradition from which it threatened to deviate and to regain the order of myth. The death of Menoeceus makes a temporary bridge between the action and the odes. After it, as we shall see, Antigone expresses in her lyrics some of the poetic ideals voiced by the chorus and tries to act in conformity with the kind of sacrificial ideal represented by Menoeceus, although this time she devotes herself to family rather than to state.

\section{The Role of Antigone}

Both Antigone in the teichoskopia and Aeschylus' chorus of native women use dochmiacs, prayers, and exclamations of fear to express their excited reaction to the enemy's encroachments. Like Aeschylus' chorus and the chorus of Phoenician women, Antigone belongs, as she stresses throughout the teichoskopia, in an enclosed peaceful realm apart from war and suffering. All of these women have as their primary positive function the performance of ritual and prayer (see I 265 and I75I-52 for Antigone's girlhood involvement in ritual). Like the chorus of Phoenician women, Antigone's initial perspective on the action is characterized by her literal as well as figurative distance from it, and by her ability to find order and brightness in the scene laid out before her. Both Anti-

55See Arthur I977: I65. 


\section{Ritual Irony}

gone and the chorus respond with sympathy through a sense of kinship to what they see before them; Antigone is full of love for her brother, and the Phoenician women see themselves as distant kin, through Io, to Thebes. Both are drawn into closer involvement in the action through their fear for the brothers. Like Antigone, Aeschylus' chorus, raising important ritual issues, confronts Eteocles to try to dissuade him from meeting his brother at the seventh gate.

When Jocasta hears of the threatened duel between the brothers, she deliberately wrenches Antigone from the enclosed virginal world of happy choruses and dance for which the Phoenician women are destined at Delphi into the unmusical world of Ares ( I 264-66):

O child Antigone, come out before the house. Not in dances or in maiden pursuits does the decree [katastasis] of the gods advance for you now.

Whereas Menoeceus, from one perspective, steps into the world of the choral odes, Antigone steps from their world into the stage action of the drama and takes up the burden of their lyrics. From this moment on Antigone explicitly dances to the tune of Ares, not to that of Apollo or the benign Dionysus, as a "bacchant of the dead" (I489-90). Both Creon (I636-38) and Oedipus try vigorously to persuade Antigone to rejoin the world of virginal contemporaries that she has left. If lines I 747-52 are genuine, Oedipus suggests that, rather than accompany him into exile, Antigone should show herself to her companions, offer prayers at the gods' altars, or go to the hills of the maenads to find Bromios and the untrod haunts (sékos, I75I-52; the chorus evokes similar haunts in the second stasimon). 56 But Antigone replies that she has entered the world of lament; the offering (charis) of dance that she once made in the thiasos of Semele, dressed in a fawnskin on the mountain, is without charis (achariton, without joy or grace, I 757) for her now.

Euripides apparently made three important additions to the ver-

56See note 45 above on the text here. 
sion of the myth given by Aeschylus and probably to that in other poets as well: Jocasta's survival through the death of the brothers; Menoeceus' sacrifice; and the joint exile of Oedipus and Antigone after the death of the brothers, which comes as an alternative to the burial of Polyneices by his sister. 57 These three supplements to the literary tradition are the only sources of unambiguously positive action and rhetoric in the plot of the Phoenissae. Jocasta's argument finds fulfillment in Menoeceus' farewell speech and sacrificial death. Antigone finds in Oedipus' exile an opportunity for heroic action, a way to gain a place in the world of poetic kleos, which Menoeceus has already attained. Exile will be painful for her and for Oedipus. But if his prophecy about Colonus is a genuine part of the text, as I believe it is, Oedipus will leave behind his ignominious concealment in the palace at Thebes to win burial, and perhaps by implication a cult in Athens (1705-9), the site of the recent heroic sacrifice of Praxithea's daughter. 58 The family of Oedipus is not simply eliminated, as in Aeschylus, but survives in part to find a new role in exile. Oedipus' disaster may unexpectedly become a source of painful opportunity.

Ironically, Antigone's attempt to follow tradition seems to result in the only action of the play that fails to achieve the expected outcome, her burial of Polyneices. 59 This naive and sheltered girl lacks the disposition requisite to fulfill her Sophoclean (and perhaps Aeschylean) role; she decides to bury Polyneices as a result of his request (I 447-50), not as a result of her own heroic inspiration. Her initial reaction to the fatal duel of the brothers is a sense of

57Robert I9I5: I, 444-45 argues that Euripides invents Antigone's accompaniment of her father into exile. Conacher 1967a: 229 thinks that Euripides also invented the sympathetic Polyneices and Oedipus' presence in Thebes during the siege. Both choices undercut the clarities of the Aeschylean plot.

${ }^{58}$ There are no impressive textual or literary reasons for excising I705-9. Oedipus does not contradict his position in $\mathrm{I} 687$, for he has now decided to accept Antigone's offer and go into exile. There are parallels (Eurytus in the Heracleidae and Polymestor in the Hecuba) for human beings making the dramatic prophecies usually reserved for gods on the machine (in this case the play has no such deus). For a good discussion see Mastronarde I 974: 538-39.

Oedipus' cult at Colonus was known to the audience, which would probably assume that burial in Athens would include Oedipus' future worship as a hero there.

${ }^{59}$ See note 44 above. 
abandonment over the loss of her promised marriage to Haimon (1436-37). Sophocles' heroine sternly reserves for her final exit her regrets concerning marriage. When Euripides' Antigone tries to act on a heroic model, the result is forceful but rather grotesque. After Creon thwarts her plan to bury Polyneices, she threatens to become a Danaid on her wedding night with Haimon (I675). Antigone's song of lament is called a mousopolon stonachan (a lament serving the Muses, I 499). 60 Commentators have remarked on the phrase, for the Muses traditionally have little to do with the world of lament and death. Yet this paradoxical phrase almost perfectly reflects Antigone's attempt to combine the bright vision of her past with her new role of lament. She appears to try to step to the tune of the choral odes in a world out of tune with her intent.

Yet, like Menoeceus, Antigone cannot bridge the gap between the world of Apollo and the world of Ares. Thebes rejects her awkward, if moving, attempt at heroism. Deprived of her traditional role and her earlier participation in the ritual life of Thebes, she persists in pursuing a second-best choice and a meaningful, more feminine destiny in her devotion to kin and private life. She determines to sacrifice herself and her marriage by accompanying her father into exile. I use the word sacrifice here to underline the symmetry, noticed by previous critics, between the actions of Antigone and Menoeceus. 61

The end of the play, even aside from its severe textual problems, makes interpretation of Antigone's role particularly difficult. Antigone and Oedipus sing past each other, and at cross purposes. The babbling old man has no interest in his daughter's attempts at heroics. ${ }^{62} \mathrm{He}$ is preoccupied with the dark world of the past, the family curse and the glory of his old encounter with the Sphinx (I728-3I), a glory already shown by the chorus to have been undercut by his later unwitting crimes. Oedipus thinks Antigone's choice to accompany him into exile is aischra (shameful, I69I) for a virgin. Antigone is impatient with her father's reminiscences about

${ }^{60}$ See Paley I 880 ad loc. on this phrase ("for, as explained on Medea I90, the Greeks seem to have regarded poetry, mousa, alien from grief and accordant only with joy") and my discussion of these issues in the Heracles chapter.

61 See esp. Rawson I970: I 23 and Garzya I962: I04.

62On Oedipus' character here, see esp. Mellon I974: I 28-33. 
the Sphinx (1732-33) and insists that her choice of solitary lament and exile is gennaia (noble, I692; see also I680). Although Oedipus finally accepts Antigone's company in exile, he seems to contest her choice to the end. Furthermore, both Polyneices and Menoeceus have disparaged exile as a mode of life (388-407, I003-5). The Phoenician maidens, on the other hand, look forward to serving Apollo in exile, and the journey from their homeland has reestablished for them the historical past and a sense of kinship with the Thebans. Antigone also chooses a life of exile and of reliving with Oedipus her city's past.

The play opens with the old Pedagogue helping Antigone mount up to a high vantage point from which to view the besiegers. This image of old leading young perhaps suggests a reversal of the proper sequence and function of the generations throughout the play. Later the blind Tiresias is led onstage from Athens by a daughter hitherto unknown in the dramatic tradition (elsewhere he is accompanied by a boy or, as in the Bacchae, walks alone). The play closes with a third image of old man and young girl; this time Antigone leads her father to Athens. Again the visual repetition may hint at the appropriate reordering of the disordered generations of the house of Laius reached at the end of the play; the young lead the old, and Oedipus and Antigone retrace the steps of Tiresias and his daughter to Athens.

Through the contrapuntal relation established between the action and the odes, Euripides opens an immense gap between the individual and the collective experience, between self-interest and the needs of the polis. The chorus and Tiresias' prophecy emphasize the roles of earth and her monsters, an intimate connection between culture and nature. Hence the chorus sees the confrontation between the brothers as one between two beasts (I 296). ${ }^{63}$ In the action, this language of poetry and prophecy is at first incomprehensible. Jocasta hears that Polyneices won his marriage to one of the daughters of Adrastus because of an oracle that predicted a confrontation between a lion and a boar (408-II). The

\footnotetext{
${ }^{63}$ Conacher I967a: 248 notes the parallel between the brothers and the other Theban monsters here. Arthur I975: 89 and Burian in Burian and Swann I 98 I: 14 view as ironic the naming of the brothers as beasts. In my view the reference underlines their final absorption into Theban myth.
} 


\section{Ritual Irony}

prophecy was fulfilled by Polyneices and Tydeus. When hearing this story, Jocasta, despite her family history, remarks in puzzlement (4I 2): "What does the name of beasts have to do with you, child?" In the same scene she is unable to make her sons view their situation in relation to the needs of the city. Until Menoeceus' sacrifice the action develops as if the past had no easily determined relation to the present. Only Jocasta, Menoeceus, the foreign chorus, and, later, Antigone and Oedipus can speak with the voice of the city, a voice in tune with history and myth.

In this play it is primarily the voices of women, of the very young and the very old, of those who stand outside or above the passions of politics, that remain in tune with the patterns of continuity in city and family life. They allow themselves in the face of an apparently resistant reality to be educated and directed by myth and ritual. The women in the chorus of the Electra, who are on their way to a festival of Hera, adopt a similar stance when they assert the therapeutic power of terrible myths even at a moment when such myths seem to stand little chance of being confirmed in reality (they doubt that the sun changed its course over Thyestes' adultery; see Electra 737-46). Whereas Creon, Eteocles, and Polyneices seem to fulfill their destinies largely through passion, Jocasta, Menoeceus, Antigone, Oedipus, and the chorus all look beyond the moment toward the gods, heroic action, the past, and the future. Jocasta in her prologue and in her speech in the agon looks back to the founding of the city, and through the present to the larger patterns that link human life to nature and the gods. Menoeceus is willing to view his life completely in relation to that of the city and its history. Oedipus insists on reviewing his past and on understanding his destiny as part of a divine pattern. Antigone, the bright-eyed visionary of the teichoskopia, moves awkwardly but insistently to a selfless commitment to her natal family, which takes her away from marriage, her childhood companions, and her city. The Phoenician maidens dedicate themselves to Apollo and to a life of celebrating myth in a foreign land through dance, song, and prayer in honor of the gods. Their vision does not deny that the forces for continuity and for violent disharmony in a community are continually held in a precarious balance. Their poetry has a sacrificial perspective. Hence it finds meaning in Me- 


\section{The Phoenissae}

noeceus' sacrifice, in a ritual that puts violence in a comprehensible context and transfers the ultimate responsibility for that violence into divine hands. For these virgins the act of Menoeceus produces a wish to bear children in his image (I060-6I). If they can do so, and we have no reason to suppose otherwise, the death of Menoeceus leaves a heroic mark on the future. 64

Herodotus recounts a series of stories in which a culture is seen to survive through women. 65 Women, even in exile and married to foreign husbands, imbue their children so strongly with the culture of their birth that the children remain more their own than those of their conquerors. At the price of exile, the lyric vision of the chorus and of Antigone moves beyond the boundaries of Thebes to Delphi and Athens, where ritual (there is no reference to politics in the mention of these places) has brought violence under control for the community.

In Aeschylus' Oresteia, the political and religious life of a city evolve together, although the final play separates the religious and secular realms and places the enforcement of justice in the male political sphere. For Euripides in the Phoenissae hope seems to lie outside politics in the same religious sphere (Delphi, burial in Athens) he is so often accused of condemning. Menoeceus' sacrifice will not cure the rotten politics of Thebes in any obvious sense, although his action sets the myth on course and temporarily ensures the safety of the city. For power is left in the hands of a leader whose patriotism is suspect, and the sacrifice of Menoeceus, hardly acknowledged by Thebes, remains primarily a source of grief to his father. Creon is not consoled by the kleos of his son; and his son, unlike some other sacrificial victims, did not act for public recognition. Ironically, the sacrifice that promises to affect the future is less that of Menoeceus than the private gesture for family made by Antigone. From the perspective of any one scene in the play, the search for salvation and a larger historical and divine pattern in events, like that presented in the odes, seems vain. This

\footnotetext{
${ }^{64} \mathrm{Kranz}$ I933: 256-61 argues that because a virgin hierodoulos cannot have children, this wish of the chorus makes no sense. The rules concerning virginity in Greek cult are far too complex for such an assumption, however. See Goossens I962: 6 I 8 on the irony of bearing children to become sacrificial victims.

${ }^{65}$ For a treatment of these issues, see Dewald I98I.
} 


\section{Ritual Irony}

impression is increased, no doubt deliberately, by the plethora of characters, the lack of alignment in the generations, and the redundant, random, or antimythical actions of the play. Yet ultimately the events of the play reveal a surprising logic and a choice, by those who depart from the city, for survival, for a destiny ultimately allied with ritual performance or a private devotion to kin and with a commemoration of the past in song. Many critics have seen in the Phoenissae (probably performed in 4IO) important links with contemporary Athenian politics: the recent return of the controversial Alcibiades from exile, the attempted mediations of Theramenes, the self-seeking and destructive factionalism of oligarchs and democrats. ${ }^{66}$ Perhaps Thebes' miraculous survival in despite of its leadership reflects Euripides' own awe at Athens' continuing escape from destruction in the face of both internal and external violence and disruption.

As Goossens remarks of Menoeceus' sacrifice, "In relation to the Heracleidae and the Erectheus, there is a kind of terrible progression in the acceptance, in the poet's consciousness, of human sacrifice as told in the old legends becoming the symbol of the demands of patriotism" (my translation). 67 Certainly Menoeceus' death is presented as a cruel and ideally unnecessary one. Human sacrifice is clearly only a legendary and literary cure for the evils of political life. Yet when Euripides invents the human sacrifice of Menoeceus to redirect his sick plot to the outcome prescribed by tradition, he seems to make a marginal gesture of confidence in ritual and in the poetry that incorporates this sacrificial cure.

${ }^{66}$ For the most extensive discussions of the play in relation to contemporary politics, see Goossens I962: 602-9 and de Romilly I967.

${ }^{67}$ Goossens 1962: 617. 